\title{
Protection of Human Rights in Countering Terrorism
}

\author{
Yu Nie \\ Guanghua Law School, Zhejiang University \\ Zhejiang 310008, China \\ E-mail: nnnyy811@gmail.com
}

\begin{abstract}
Although the violent action occurred increasingly in the world, the definition of terrorism has not come into consensus yet. In countering terrorism, human right protection for the terrorist suspects should also be guaranteed, for the "fair" trial and the minimum procedural guarantees are the basic element of the rule of law. Moreover, the terrorist suspects should be protected by the minimum standard of the fair trial even if before the military commission. Because the minimum due process guarantees for a fair trial may not be suspended even if the life of the nation is threatened, the procedural rights of the terrorist suspects should be regarded as non-derogable.
\end{abstract}

Keywords: Terrorism, Military commission, Fair trial

\section{Introduction}

While the violent action occurred increasingly such as the "September 11th" event, how to identify the nature of terrorism and find proper measures to solve these problems are becoming critical issues. The United Nations General Assembly resolution reaffirmed that States are under the obligation to protect all human rights and fundamental freedoms of all persons. (Note 1) The right to a fair trial is a guarantee in the ever increasing effort to create and maintain standards for human rights at the international, as well as the national, level. (Note 2) A fair trial is a basic element of the notion of the rule of law, (Note 3) and the principles of 'due process' and 'the rule of law' are fundamental to the protection of human rights. (Note 4) Human right protection for the terrorist suspects should also be guaranteed while countering terrorism, let alone terrorism haven't not being clearly defined.

Firstly, this paper will explain the meaning and content of terrorism within the broader regime of international law. Secondly, this paper analyzes the legitimacy of the U.S. military trials in line with the ICCPR fair trial standards, with the conclusion that the U.S. military procedure involves multiple violations of core guarantees. Thirdly, the paper demonstrates the idea of preserving the core guarantees of due process incorporated in the principle of a fair trial, such as the independence and the impartiality of the court, the right to legal assistance, the right to a trial without undue delay, the right to habeas corpus, the presumption of innocence, the right to appeal and so on. Finally, this paper addresses the issue of non-derogation from the right to a fair trial as an intrinsic step in promoting the rule of law on a universal scale, arguing that the existing International Covenant on Civil and Political Rights (ICCPR) system is broad enough to cover any emergency situations.

\section{The terrorism}

The International Convention for the Suppression of the Financing of Terrorism has two standards to define Terrorism. One is the activity covered by the twelve anti-terrorism treaties. The other one is any other actions intended to cause death or serious bodily injury to a civilian, or to person not taking an active part in the hostilities in a situation of armed conflict, when the purpose of such act, by its nature or context, is to intimidate a population, or to compel a Government or an international organization to react or not.

In this instance, People's struggle including defense against foreign occupation, aggression, colonialism, and hegemony, aiming at liberation and self-determination in accordance with the principles of international law shall not be considered as a terrorist crime. (Note 5) Although the acts of terrorism are frequently regarded as the "armed conflict threshold", the International Humanitarian Law (IHL) conventions do not apply to "situations of internal disturbances and tensions such as riots and isolated and sporadic acts of violence." (Note 6)

In a word, since the definition of terrorism has never come into consensus, the assumptions of terrorism should not be random. The judgment of a terrorist crime could only be made after scrutinizing all existing counter-terrorism 
conventions in order to prove the crime matches any of the defined actions, which was expressed in numerous past General Assembly and Security Council resolutions.

\section{Military commission}

Common Article 3 of the 1949 Geneva Conventions (Note 7) requires a trial by "a regularly constituted court affording all the judicial guarantees which are recognized as indispensable by civilized peoples". (Note 8) "A regularly constituted court" means a court established and organized in accordance with the laws and procedures already in force in a country. (Note 9) It includes an ordinary military court set up in accordance with the recognized principles governing the administration of justice, (Note 10) and definitely excludes all special tribunals. (Note 11) Additionally, an acceptable degree of independence from the Executive is necessary for a commission to be regularly constituted. (Note 12)

After September 11, 2001, in response to the terrorist attacks that represented an increased threat to the security of both the Unites States and the international community, President Bush issued a Military Order (Note 13) to establish special military commissions for individual non-citizens suspected of involvement in terrorist attacks.

Military commissions can be designed for several purposes: (1) to prosecute violations of the law of war, as an alternative to courts-martial; (2) to fill a legal vacuum where armed conflict disables the civil courts; and (3) to impose swift and certain punishment against civilians suspected of specific crimes. One of the key reasons why the Bush Administration opted to create the military commissions for trying terrorism cases was the desire to use classified information. By trying before military commission, the government would not have to face a dilemma in some instances -- whether to reveal the classified information or drop the prosecution and free the defendant. In the Hamdan case, Justice Stevens maintained that the military commission created by President Bush "lacks power to proceed because its structure and procedures violate the Geneva Conventions". Thus, military commission is neither a legitimate mechanism of accountability nor "a regularly constituted court", rather, they are something like a kangaroo court. The commission tends to hide the very facts and principles that should be announced to the world, which have been perceived as granting judgments based on politics, not legal norms.

Moreover, "all the judicial guarantees which are recognized as indispensable" necessarily incorporates a minimum set of due process guarantees under customary international law. The Common Article 3 of the 1949 Geneva has long been regarded as a minimum baseline of rights that must be afforded to all prisoners. It applied to the non-international armed conflict against al Qaeda. Accordingly, military commission procedure had to comply with the minimum procedural requirements of Common Article 3. Article 5 of the Convention provides that persons captured during an international armed conflict are entitled to the protections of the treaty even if their identity as POWs as defined by Article 4 is in doubt, until a competent tribunal has determined their status.

Thus, even if the detainees are accused of the terrorist, they are entitled to POW status and their basic human rights especially the due process guarantees in a fair trial should be protected.

\section{Due process and Non-derogation}

\subsection{Due process}

When the terrorist suspects face the court, they should be granted to basic procedural rights. These basic procedural rights have been described in a number of international human rights and humanitarian instruments, specifically, in article 14 of ICCPR, article 75 of Additional Protocol I and article 6 of Additional Protocol II to the Geneva Conventions.

ICCPR reflects what the international community now recognizes as a set of minimum due process guarantees under customary human rights law. These minimum standards include a fair and public hearing before a "competent, independent and impartial tribunal established by law", (Note 14) the presumption of innocence, (Note 15) due process rights, which includes the right to counsel of one's choice, to effective representation (Note 16), to examine or have examined witnesses against the accused, to be tried without undue delay, and to not be compelled to testify against oneself or to confess guilt. (Note 17) Likewise, the UN Human Rights Committee acknowledged that the trying by military commission, if not prohibited by the ICCPR, should be very exceptional and taking place under conditions which genuinely afford the full guarantees stipulated in Article 14. (Note 18)

Therefore, any internal law must be narrowed to comply with jurisdictional limits mandated by humanitarian law and the derogation requirements of ICCPR. Due process guarantees include those necessary for fairness at the trial stage and pre- or post-trial procedures. However, the minimum due process guarantees, in particular, refer to the former rights, namely the basic procedural rights at the trial stage. (Note 19) Furthermore, the minimum due process rights under discussion should never be suspended. 


\subsection{Non-derogation}

Rights guaranteed by a treaty are not necessarily inviolable; treaties may provide for reservation or derogation in specific circumstances. The major impetus behind derogation clauses is to balance between the rights of an individual and the rights of a state, and to maintain the flexibility in times of emergency.

However, there is a baseline. International human rights law creates_strict human rights standards at the meanwhile to limit such derogation. That is, derogations are acceptable only if they are necessary, proportional, not in conflict with non-derogable provisions, as well as subject to international scrutiny and review.

Firstly, with regard to the necessity test, a state of emergency is required. Specifically, Emergency must "imperil some fundamental element of statehood or survival of the population," (Note 20) be provisional or temporary in scope, (Note 21) be imminent, (Note 22) and be of such character that it threatens the nation as a whole. In the Greek Case, European Commission on Human Rights held that, the condition of political instability and tension combined with public disorder did not create a situation of public emergency. (Note 23)

Secondly, in respect of the proportionality test, derogative measures must be proportional in duration, (Note 24) severity, (Note 25) and geographic scope (Note 26), connected to the emergency such that they are prima facie suitable to reduce the crisis (Note 27), and be a showing that ordinary measures are insufficient. (Note 28) Indeed, the fact that trials of Al Qaeda operatives have been successfully conducted in federal court, without disrupting or compromising national security, strongly challenges the necessity to try before military commission. The Human Rights Committee has looked to the proportionality of derogation in a number of cases including review of the Colombian Report, where more information was requested on the extension of military jurisdiction; the El Salvador Report, where derogation to fundamental rights of due process seemed unnecessary; and the Uruguayan report, where it was found that measures against certain groups were "repressive and out of proportion to the threat."

Thirdly, derogative measures should be consistent with other obligations under international law, such as the non-derogable provisions and jus cogens norms.

In order to interpret article 4 of ICCPR, and respond to US military commission established by President Bush, the UN Human Rights Committee issued General Comment No 29 in August 2001. This comment addresses two different issues relating to fair trial rights --- first is the link between certain procedural protections and the preservation of non-derogable rights, and second is the significance of the strict proportionality rule. Non-derogable rights must be secured by procedural guarantees, including judicial guarantees. (Note 29) In this regard, the Human Rights Committee questioned the suspension of the fair trial rights by US military commission, which may fail the test of proportionality. Safeguards related to derogation are based on the principles of legality and the rule of law inherent in the Covenant as a whole. As certain elements of the right to a fair trial are explicitly guaranteed under international humanitarian law during international armed conflict, the Committee held that the principles of legality and the rule of law require that fundamental requirements of fair trial must be respected during a state of emergency. General Comment No. 29 thus does not suggest an absolute bar on military trials of civilians, but it does indicate that the military commissions under consideration here must comply with international humanitarian law and must not deny fair trial rights.

Furthermore, the idea that the list of non-derogable rights should be expanded to include the right to a fair trial has gained acceptance and support from the international community. For example, the American Convention of Human Rights (ACHR) does list the right to a fair trial as non-derogable. (Note 30) Article 67 of the Rome Statute (Note 31) enunciates a number of "necessary" minimum guarantees, which specifically includes those rights discussed above. (Note 32) The $61^{\text {st }}$ Conference of the International Law Association approved by consensus a set of minimum guarantees for a fair trial to be listed as non-derogable. (Note 33) Additional support is supplied by the Queensland Guidelines, which illustrate another step toward general recognition of the right to fair trial as non-derogable. (Note 34)

Therefore, the minimum due process guarantees for a fair trial may not be suspended even if the life of the nation is threatened, and the procedural rights of the terrorist suspects should be regarded as non-derogable.

\section{Conclusion}

Before the military commission the accused should be protected by the minimum standard of the fair trial. Fair trial rights have, observably, been provided for at the international and national levels. Their imperative nature has been emphasized by various human rights bodies--the UN Human Rights Committee, the European Court, the Inter-American Commission and Court, and the African Commission. The above bodies have also adopted a similar approach with regard to the relation between fair trial rights and the right to life, finding the imposition of the penalty after an unfair trial to constitute a violation of the human rights.

The idea that the list of non-derogative rights should implicitly incorporate core fair trial guarantees is receiving more acceptances in the international community. The role of the fair trial in building democracy and the rule of law cannot 
be simply replaced with unilateral policy for combating international terrorism. The due process for the terrorist suspects should be non-derogable from the main safeguard of the right to a fair trial.

\section{References}

4 Int'l Comm. of Red Cross. (1958). Commentary: Geneva Convention Relative to the Protection of Civilian Persons in Time of War 340.

Alexander Charles Kiss. Permissible Limitations on Rights in the International Bill of Rights: The Covenant on Civil and Political Rights, in The International Bill of Rights 290.

Barbara M.Yarnold. (1991). International Fugitives-A New For the International Court Of Justice, 63-66.

C Ovey and R White. The European Convention on Human Rights (OUP New York 2002), 139.

C.F. D. Osborn. (2000). Suppressing the Trueth: Judicial Exclussion of Illegally Obtained Evidence in the United States, Canada, England And Australia, VOL. VII, NO. 4.

David Harris. (1967). The Right to a Fair Trial in Criminal Proceedings as a Human Right. 16 Int'l \& Comp. L.Q. 352.

Fionnuala Ni Aolain. (1995). The Emergence of Diversity: Differences in Human Rights Jurisprudence. 19 Fordham Int'l L. J. 101, 141.

Geneva Convention Relative to the Treatment of Prisoners of War art. 3, Aug.12, 1949, 6 U.S.T. 3316, 75 U.N.T.S. 135.

Hamdan v. Rumsfeld, 126 S. Ct. 2749 (U.S. 2006), at 2804.

Helen Duffy. (2005). The War On Terror And The Framework Of International Law, 112.

Human Rights Committee. (1984). General Comment Apr. 12.

Int'l Comm. of Red Cross. (2005). 1 Customary International Humanitarian Law 355.

International Covenant on Civil and Political Rights. (1966). Dec. 16, 999 U.N.T.S. 171.

Jaime Oraá. (1992). Human Rights in States of Emergency in International Law 14.

Joan Fitzpatrick. (1994). Human Rights in Crisis, The International System for Protecting Rights During States of Emergency.

Louise Doswald-Beck \& Robert Kolb. (2004). Judicial Process and Human Rights: United Nations, European, American and African System, Text and Summaries of International Case-Law, International Commission of Jurists.

Malcolm N.Shaw. (2005). International Law (5th ed.), 585.

Military Order of Nov. 13, 2001- Detention, Treatment, and Trial of Certain Non-citizens in the War Against Terrorism, 66 Fed. Reg. 57833 (Nov. 13, 2001).

Nowak \& Manfred. (1993). Un Covenant On Civil And Political Rights, Ccpr Commentary, 126-141.

Queensland Guidelines for Bodies Monitoring Respect for Human Rights During States of Emergency, approved at the 64th conference of the International Law Association's Committee on Enforcement of Human Rights Law.

R Clayton and H Tomlinson. Fair Trial Rights (OUP New York 2001), 2.

R. St. J. Macdonald. (1997). Derogations under Article 15 of the European Convention on Human Rights. 36 Colum. J. Transnat'1 L. 225, 225, at 233-34.

Robert Jennings \& Arthur Watts. (1992). Oppenheim'S International Law (9th ed.), VOL.I, 456.

Subrata Roy Chowdhury. (1989). Rule of Law in a State of Emergency.

Surya P. Subedi. (2002). The U.N. Response to International Terrorism in the Aftermath of the Terrorist Attacks in America and the Problem of the Definition of Terrorism in International Law. 4 INT'L LAW F. DU DROIT INT'L 163.

T. Meron. (1987). Human Rights in Internal Strife: Their Protection, 40.

The Greek Case, Report of the European Commission and the European Court of Human Rights, 12 Y.B. Eur. Conv. on H.R.

The report of the Third Committee of United Nations General Assembly (A/61/443/Add.2 and Corr.1)

Thomas Buergenthal \& Sean D. Murphy. (2004). Public International Law, 211.

Waldemar Solf. (1983). The Status of Combatants in Non-International Armed Conflicts Under Domestic Law and Transnational Practice. 33 AM. U.L. REV. 53, Article 1(2) of Protocol II.

\section{Notes}

Note 1. See the report of the Third Committee of United Nations General Assembly (A/61/443/Add.2 and Corr.1) 
Note 2. See David Harris, The Right to a Fair Trial in Criminal Proceedings as a Human Right, 16 Int'l \& Comp. L.Q. 352 (1967) ("The right to a fair trial has figured prominently in the efforts made in recent years to guarantee human rights at an international level.").

Note 3. C Ovey and R White The European Convention on Human Rights (OUP New York 2002) 139.

Note 4. R Clayton and H Tomlinson Fair Trial Rights (OUP New York 2001) 2.

Note 5. Surya P. Subedi, The U.N. Response to International Terrorism in the Aftermath of the Terrorist Attacks in America and the Problem of the Definition of Terrorism in International Law, 4 INT'L LAW F. DU DROIT INT'L 163 (2002).

Note 6. Waldemar Solf, The Status of Combatants in Non-International Armed Conflicts Under Domestic Law and Transnational Practice, 33 AM. U.L. REV. 53, 62-63 (1983), Article 1(2) of Protocol II.

Note 7. Geneva Convention Relative to the Treatment of Prisoners of War art. 3, Aug.12, 1949, 6 U.S.T. 3316, 75 U.N.T.S. 135 [hereinafter Geneva III].

Note 8. Geneva III, supra note 8, art. 3.1(d).

Note 9. Int'l Comm. of Red Cross, 1 Customary International Humanitarian Law 355 (2005).

Note 10. 4 Int'l Comm. of Red Cross, Commentary: Geneva Convention Relative to the Protection of Civilian Persons in Time of War 340 (1958).

Note 11. Ibid.

Note 12. Hamdan v. Rumsfeld, 126 S. Ct. 2749 (U.S. 2006), at 2804 (plurality opinion).

Note 13. Military Order of Nov. 13, 2001- Detention, Treatment, and Trial of Certain Non-citizens in the War Against Terrorism, 66 Fed. Reg. 57833 (Nov. 13, 2001) [hereinafter Military Order].

Note 14. ICCPR, art. 14, para. 1.

Note 15. ICCPR, art. 14, para.2.

Note 16. ICCPR, art. 14, para. 3(b)(d).

Note 17. ICCPR, supra note 14, art. 14, para.3(c)(e)(g).

Note 18. Human Rights Committee, General Comment No. 13, para. 4 , Apr. 12, 1984.

Note 19. Pre- or post-trial procedure rights include: (1) freedom from arbitrary arrest, see Banjul Charter, supra note 3 , art. 6; ACHR, supra note 3, art. 7(3); ICCPR, supra note 3, art. 9(1); ECHR, supra note 3, art. 5; UDHR, supra note 3, art. 9; (2) the right to be informed promptly and in detail in a language which he understands the nature and cause of the charge against him, see Additional Protocol I, supra note 3, art. 75(3); Additional Protocol II, art. 6(2)(a); ICCPR, supra note 3, art. 14(3)(a); ECHR, supra note 3, art. 6(3)(a); (3) the right to have adequate time and facilities for preparation of defense and the right to communicate with counsel, see ACHR, supra note 3, art. 8(2)(c),(d); ICCPR, supra note 3, art. 14(3)(b); ECHR, supra note 3, art. 6(3)(b) (does not include communication with counsel); (4) the right to be tried without undue delay, see Banjul Charter, supra note 3, art. 7(d); ACHR, supra note 3, art. 8(1); ICCPR, supra note 3, art. 14(3)(c); ECHR supra note 3, art. 6(1); and (5) the right to review of conviction and sentence by a higher tribunal, see ACHR, supra note 3, art. 8(2)(h); ICCPR, supra note 3, art. 14(5).

Note 20. See Joan Fitzpatrick, Human Rights in Crisis, The International System for Protecting Rights During States of Emergency 38-41 (1994), at 56.

Note 21. See Subrata Roy Chowdhury, Rule of Law in a State of Emergency (1989).

Note 22. See Jaime Oraá, Human Rights in States of Emergency in International Law 14 (1992), at 27.

Note 23. See The Greek Case, Report of the European Commission and the European Court of Human Rights, 12 Y.B. Eur. Conv. on H.R., para. 165 (1969). In 1967, the military took power in Greece, replaced the legitimate government, declared martial law, suspended many articles of the constitution, and took control of the government. In the process, the military placed many of the opposition leaders in prison. At this time, Greece declared a state of emergency and claimed the ability to derogate from certain rights. After a number of countries objected to this proclamation, the case came before the Commission. It concluded that violations of the convention were not justified, as the "public emergency" declared was not of the magnitude or character necessary for derogation. The Commission applied an "objective test" that required "strong proof" of an actual emergency. According to the Commission, the condition of political instability and tension combined with an increase in communist activity and public disorder did not create a situation of public emergency.

Note 24. See Oraá, 23, at 143. 
Note 25. See Fionnuala Ni Aolain, The Emergence of Diversity: Differences in Human Rights Jurisprudence, 19 Fordham Int'l L. J. 101, 141 (1995), at 127.

Note 26. See Alexander Charles Kiss, Permissible Limitations on Rights in the International Bill of Rights: The Covenant on Civil and Political Rights, in The International Bill of Rights 290.

Note 27. See R. St. J. Macdonald, Derogations Under Article 15 of the European Convention on Human Rights, 36 Colum. J. Transnat'l L. 225, 225 (1997), at 233-34.

Note 28. See id.

Note 29. For example, as article 6 [the right to life] is non-derogable in its entirety, any trial leading to the imposition of the death penalty during a state of emergency must conform to the provisions of the Covenant, including all the requirements of articles 14 [fair trial] and 15 [prohibition on retroactive penalties].

Note 30. The ACHR explicitly prohibits derogation from the right to judicial guarantees essential for the protection of non-derogable rights.

Note 31. The Rome Statute provides for many of the rights of the accused recognized by the international community as necessary under major human rights instruments, humanitarian, and/or customary law.

Note 32. The right to be "tried without undue delay;"--- art. 67(1)(c); "to examine, or have examined, the witnesses against him or her and to obtain the attendance and examination of witnesses on his or her behalf under the same conditions as witnesses against him or her;" --- art. 67(1)(e); "not to be compelled to testify or confess to guilt." --- art. $67(1)(\mathrm{g})$

Note 33. In 1984, the 61st Congress of the ILA approved by consensus "a set of minimum standards governing the declaration and administration of states of emergency that threaten the life of a nation, including sixteen articles setting out the non-derogable freedoms to which individuals remain entitled even during states of emergency." The proposed non-derogable right to a fair trial includes all of the procedural components discussed above.

Note 34. Queensland Guidelines for Bodies Monitoring Respect for Human Rights during States of Emergency, approved at the 64th conference of the International Law Association's Committee on Enforcement of Human Rights Law. 